\title{
Evaluation of Oral Anticoagulant Usage Satisfaction in Home Care Patients Using Warfarin
}

\author{
(1) Samet Akgün1, (1) Sibel Tunç Karaman2, (1) Sonay Özdemir2, (1) Okcan Basat2 \\ ${ }^{1}$ Emirgazi State Hospital, Clinic of Family Medicine, Konya, Turkey \\ ${ }^{2}$ University of Health Sciences Turkey, Gaziosmanpaşa Training and Research Hospital, Clinic of Family Medicine, İstanbul, Turkey
}

Cite this article as: Akgün S, Tunç Karaman S, Özdemir S, Basat O. Evaluation of Oral Anticoagulant Usage Satisfaction in Home Care Patients Using Warfarin. J Acad Res Med 2021;11(1):38-45

\begin{abstract}
Objective: Warfarin is the most commonly used oral anticoagulant for the prevention and treatment of thromboembolic diseases. However, the difficulty of treatment management adversely affects patient satisfaction. The objective of this study is to measure the satisfaction of using warfarin among home care patients and determine the factors affecting their satisfaction levels.

Methods: This descriptive study was performed with patients who used warfarin and registered at the Home Health Care Services Unit of a tertiary hospital between May 2017 and November 2017. Importantly, the sociodemographic and clinical features of the patients were determined. Patients' satisfaction with drug use was evaluated using the Duke Anticoagulant Satisfaction Scale (DASS).

Results: The ages of 97 patients included in the study ranged from 19 to 92 years; moreover, $71.1 \%(n=69)$ of the patients were women. In total, $41.2 \%$ $(n=40)$ of the patients have had haemorrhagic events during the use of warfarin. The DASS mean score of the patients was $57.67 \pm 14.56,20.46 \pm 5.89$ for the limitations with the treatment, $21.54 \pm 7.46$ for the hassles and burdens, and $15.67 \pm 4.87$ for the positive impacts. It was determined that the number of additional chronic diseases and bleeding conditions while using warfarin had a significant effect on the total score and subscale scores of DASS (for total score, $\mathrm{p}=0.046$; for subscale scores, $\mathrm{p}<0.001$ ) and reduced satisfaction.

Conclusion: This study found that satisfaction with warfarin use was not poor in home care patients, but the history of bleeding and the number of additional chronic diseases worsened the treatment satisfaction. It is believed that their satisfaction can be increase, if counselling interventions are planned according to the needs of patients.

Keywords: Anticoagulants, homecare services, patient satisfaction, warfarin
\end{abstract}

\section{INTRODUCTION}

Home health and care services are defined as a comprehensive care model covering psychological, physiological and medical support services in the living environment of patients. This care model comprises follow-up care, diagnosis and post-treatment care of the elderly; visits of people with chronic disease, disability or recovery; or providing preventive health services to those without a health problem. A regular follow-up of patients using oral anticoagulant (OAC) drugs, especially warfarin, is a crucial part of home health care (1).

OAC drugs are used in both the treatment and prevention of diseases such as arterial and venous thromboembolism, heart

ORCID IDs of the authors: S.A. 0000-0003-1183-7570; S.T.K. 0000-0003-1833-8758; S.Ö. 0000-0002-3511-5727; 0.B. 0000-0002-5222-9136.

Received Date/Geliş Tarihi: 07.09.2020 Accepted Date/Kabul Tarihi: 19.01.2021

CCopyright 2021 by University of Health Sciences Turkey, Gaziosmanpaşa Training and Research Hospital. Available on-line at www.jarem.org 
valve diseases, atrial fibrillation and stroke. As the frequency of such diseases, which are important causes of morbidity and mortality, increases with ageing, there is also an increase in the use of OAC drugs $(2,3)$. These drugs inhibit the coagulation event or reduce the coagulation ability of the blood by disrupting the function or synthesis of coagulation factors (4).

Warfarin, a vitamin $\mathrm{K}$ antagonist, is the first-choice OAC drug for the prophylaxis and treatment of thromboembolic diseases (5). Many complications can arise during its usage (6). It holds a vital importance in keeping the international normalised rate (INR) value, which is used in evaluating the drug efficacy at the target limit (7). In warfarin treatment, the lack of standardised dosing, narrow treatment intervals, the need for a strict laboratory followup, interaction of multiple drugs and nutrients, and the risk of major and minor side effects negatively impact the benefits and reliability of the drug and decrease the quality of life (8-10).

It was observed that the majority of the patients had insufficient knowledge about anticoagulant treatment management and that the treatment could not be managed well due to the complications arising from bleeding and multiple drug use. Especially with the advancement of age, patients' compliance with the treatment decreased (11-13).

Although it is known that compliance with the treatment is crucial for patient satisfaction, some measurement tools have been developed to determine the treatment satisfaction in patients using anticoagulants $(11,14-16)$. There are a limited number of studies investigating the satisfaction of these patients and effects on treatment (13,17-21).

The objective of this study is to measure the satisfaction of patients who were receiving home care services due to warfarin use and, also, evaluate the relationship between patients' sociodemographic and clinical characteristics along with their satisfaction levels.

\section{METHODS}

This prospective study was planned as a single-centre, descriptive study. Ethics committee approval was obtained from the relevant institution on 05.04.2017 (approval number: 36). The study was conducted in compliance with the Declaration of Helsinki's recommendations. The objective of the study was explained to all the participants, and their informed consent was obtained before their participation in the study.

\section{Study Population}

The study was conducted between 01.05.2017 and 01.11.2017 with patients who were registered to Home Health Care Services of a tertiary hospital and were receiving warfarin treatment. In total, 97 people aged 18 years and above who did not have any communication problems and agreed to participate in the study were included. Patients aged less than 18 years, those with severe psychiatric diseases, and those who could not communicate verbally were excluded from the study.

\section{Data Collection Tools}

\section{Patient Information Form}

The sociodemographic and clinical characteristics of the patients were questioned (determined) via the face-to-face interview technique using the patient information form prepared by us. It covers the questions regarding the sociodemographic (age, gender) and clinical features of the patients (the reason for using $O A C$, duration of use, whether they experience bleeding or thromboembolic events during the use of OAC or additional diseases).

\section{Duke Anticoagulant Satisfaction Scale}

Duke Anticoagulant Satisfaction Scale (DASS), developed by Samsa et al. (14) in 2004, and the Turkish validity and reliability study, conducted by Yıldıım and Bayık-Temel (13) in 2014, were used to evaluate patients' satisfaction with drug use. This scale, which allows health care professionals to evaluate the quality of life and satisfaction of patients receiving anticoagulant treatment, shows the patient's perception of treatment, quality of life and the level of disease management. It is a 7-point Likert-type scale comprising 25 items and a 3-factor structure: "Limitations", "burdens and difficulties" and "positive effects". It is measured with a rating of total score of the scale and the average score of each subdimension: " $1=$ none", " $2=$ very little", " $3=$ a little", " $4=$ moderately", " $5=$ a bit more", " $6=$ much" and " $7=$ very much". In the scale, questions $17,18,19,21,23$ and 25 are reverse-coded. The lowest score on the scale is 25 , and the highest score is 175 points. High scores indicate a poorer quality of life and satisfaction with anticoagulant treatment $(13,14)$. The alpha coefficient $(0.89)$ determined for the overall scale form and the alpha coefficients (0.78-0.91) determined for the scale and its subdimensions are considered to be highly reliable (13).

\section{Statistical Analysis}

IBM SPSS Statistics 22 (IBM SPSS, Turkey) programme was used for the statistical analysis of this study's data. While evaluating the data, the compliance of the parameters to the normal distribution was evaluated with the Shapiro-Wilk test. In addition to descriptive statistical methods (mean, standard deviation, frequency), OneWay ANOVA test was used for intergroup quantitative data comparison with normally distributed parameters. The Tukey honestly significant difference test and Tamhane's T2 test were used to determine the group that caused the difference. The Student's t-test was used for comparing the normally distributed parameters between the two groups. Significance was considered at the level of $p<0.05$.

\section{RESULTS}

This study was performed with 97 patients whose ages ranged between 19 and 92 years (mean: $72.52 \pm 14.23$ years). Most of the participants were aged 65 years and above $(n=72,74.2 \%)$, and $22.7 \%(n=22)$ of them were aged between 40 and 64 years. In total, $71.1 \%(n=69)$ of the patients were women, $95.9 \%(n=93)$ 
had an additional chronic disease, and $41.2 \%(n=40)$ experienced bleeding under warfarin treatment. Table 1 shows the evaluation of patients according to their sociodemographic and clinical features.

Apart from existing diseases requiring anticoagulant use, the most common additional chronic diseases were hypertension $(63.9 \%, n=62)$, cerebrovascular diseases $(33 \%, n=32)$ and chronic ischemic heart disease $(27.8 \%, \mathrm{n}=27)$.

As shown in Table 2, the mean total DASS score of the patients was $57.67 \pm 14.56$ (minimum: 36 , maximum: 103), the subdimension mean score of limitations was $20.46 \pm 5.89$, the subdimension mean score of burdens and difficulties was $21.54 \pm 7.46$ and the

\begin{tabular}{|c|c|c|c|}
\hline & & $\mathrm{n}$ & $\%$ \\
\hline \multirow{3}{*}{ Age groups } & $<40$ & 3 & 3.1 \\
\hline & $40-64$ & 22 & 22.7 \\
\hline & $\geq 65$ & 72 & 74.2 \\
\hline \multirow{2}{*}{ Gender } & Female & 69 & 71.1 \\
\hline & Male & 28 & 28.9 \\
\hline \multirow{3}{*}{$\begin{array}{l}\text { Additional chronic } \\
\text { disease }\end{array}$} & No & 4 & 4.1 \\
\hline & $1-2$ & 68 & 70.1 \\
\hline & $\geq 3$ & 25 & 25.8 \\
\hline \multirow{4}{*}{$\begin{array}{l}\text { Anticoagulant use } \\
\text { reason }\end{array}$} & Atrial fibrillation & 63 & 64.9 \\
\hline & Heart valve replacement & 19 & 19.6 \\
\hline & Deep vein thrombosis & 10 & 10.3 \\
\hline & Pulmonary embolism & 5 & 5.2 \\
\hline \multirow{4}{*}{$\begin{array}{l}\text { Anticoagulant use } \\
\text { period }\end{array}$} & $<2$ years & 20 & 20.6 \\
\hline & $2-5$ years & 32 & 33.0 \\
\hline & $6-10$ years & 22 & 22.7 \\
\hline & $\geq 10$ years & 23 & 23.7 \\
\hline \multirow{3}{*}{ History of bleeding } & No & 57 & 58.8 \\
\hline & Minor bleeding & 30 & 30.9 \\
\hline & Major bleeding & 10 & 10.3 \\
\hline \multirow{2}{*}{$\begin{array}{l}\text { Thromboembolic } \\
\text { events }\end{array}$} & No & 89 & 91.8 \\
\hline & Yes & 8 & 8.2 \\
\hline
\end{tabular}

Table 2. Evaluation of Duke Anticoagulant Satisfaction Scale results

\begin{tabular}{|c|c|c|c|}
\hline $\begin{array}{l}\text { Subdimensions of the } \\
\text { scale }\end{array}$ & Min-max & Mean \pm SD & $\begin{array}{l}\text { Cronbach's } \\
\text { alpha }\end{array}$ \\
\hline Limitation with treatment & $11-42$ & $20.46 \pm 5.89$ & 0.756 \\
\hline Burdens and difficulties & $11-44$ & $21.54 \pm 7.46$ & 0.834 \\
\hline $\begin{array}{l}\text { Positive psychological } \\
\text { impact }\end{array}$ & $6-28$ & $15.67 \pm 4.87$ & 0.739 \\
\hline Total score & $36-103$ & $57.67 \pm 14.56$ & 0.871 \\
\hline
\end{tabular}

subdimension mean score of positive effects was $15.67 \pm 4.87$ (Table 2).

Table 3 shows the distribution of DASS items and responses.

Table 4 presents the evaluation of results according to the sociodemographic and clinical features of participants. It was determined that the number of additional chronic diseases other than diseases requiring the use of $O A C$ and bleeding status while using warfarin had a significant effect on the total score and subscale scores of DASS

A statistically significant relationship was found between the number of additional chronic diseases and the mean scale score $(p=0.046)$. The mean total score scores of patients with three or more chronic diseases were found to be significantly higher than those with one chronic disease and two chronic diseases $\left(p^{1}=0.021 ; p^{2}=0.038\right)$ (Table 4).

A statistically significant relationship was found between the number of chronic diseases and the subdimension mean of burden and difficulties $(p=0.022)$. As a result of the binary comparisons made for the detection of difference, the average burden and difficulties subdimension of patients with three or more chronic diseases were found to be statistically significantly higher than those with a chronic disease $(p=0.029)$ (Table 4).

A statistically significant relationship was found between bleeding history and the total scale score averages $(p<0.001)$. The total scale point averages of those who did not experience bleeding were statistically significantly lower than those who suffered minor bleeding $(p=0.002)$ and those who suffered major bleeding $(p=0.001)$ (Table 4).

A statistically significant difference was found between bleeding status in terms of the subdimension means of limitations and burden and difficulties ( $p=0.001$ and $p=0.001$, respectively). The subdimension mean scores of limitations and burden and difficulties of those who did not experience bleeding were statistically significantly lower than those who suffered major bleeding ( $p=0.001$ and $p=0.007$, respectively) (Table 4).

No statistically significant difference was found in terms of subscale mean scores of age, gender, causes of anticoagulant use, duration of anticoagulant use, thromboembolic events and total scale score, restrictions, burdens and difficulties and positive effects (Table 4).

\section{DISCUSSION}

This study found that drug satisfaction was not deficient in home care patients using warfarin, but the history of bleeding during the use of warfarin and the presence of additional chronic disease worsened treatment satisfaction. It was observed that age, gender, the reason for using $O A C$, duration of using $O A C$ and having a thromboembolic event did not affect the overall satisfaction level and subdimensions of the scale.

As mentioned, our study group comprises people who used warfarin for any reason and needed home care services because 
of additional diseases and/or advanced age, etc. Therefore, it was concluded that even if they are limited in terms of working life, daily work and travel, they are not adversely affected by warfarin use.
Home health and care services are provided to patients of any age group with chronic diseases that restricts their daily life activities, mostly for patients aged 65 and over (22). Karaman et al.'s (23) study determined that $88.1 \%$ of the patients were aged 65 years

Table 3. Distribution of Duke Anticoagulant Satisfaction Scale items

1. How much does the possibility of experiencing bruising or bleeding restrict your participation in physical activities (e.g. housework, gardening, dancing, doing sports, and other activities)?

2. How much does the possibility of experiencing bruising or bleeding restrict your travel?

3. How much does the possibility of experiencing bruising or bleeding restrict the medical care you need (e.g. visiting a dentist, massage treatment, or going to another doctor)?

4. How much does the possibility of experiencing bruising or bleeding restrict your working life?

5. When you consider all these features above, how much does the possibility of bruising or bleeding affect your daily life?

6. How much does the anticoagulant treatment restrict your food choices (diet)?

7. How much does anticoagulant treatment restrict you from drinking alcoholic beverages when you want?

8. How much does the anticoagulant treatment restrict using over-the-counter medicines (aspirin, ibuprofen, vitamins, herbal remedies)?

9. When you consider all these features above, how much does anticoagulant treatment affect your daily life?

10. How much does the anticoagulant treatment make it difficult for you to do your daily responsibilities?

11. How much does the anticoagulant treatment complicate your changing responsibilities when necessary?

12. How complex do you find the anticoagulant treatment?

13. How much time do you think you lost due to anticoagulant treatment?

14. How much do you think the anticoagulant treatment is frustrating?

15. How much do you think the anticoagulant treatment is demoralising?

16. When you consider all these features above, how much difficulty/burden does anticoagulant treatment bring to you?

20. How much do you worry if you experience bruising and bleeding due to your anticoagulant treatment?

22. When you consider all these features above, how much does the anticoagulant treatment have a negative effect on your life?

24. Compared to the medical treatments you have taken, what is the difficulty of managing the anticoagulant treatment for you?

\begin{tabular}{|c|c|c|c|c|c|c|}
\hline None & Very little & A little & Moderately & $\begin{array}{l}\text { A bit } \\
\text { more }\end{array}$ & Much & $\begin{array}{l}\text { Very } \\
\text { much }\end{array}$ \\
\hline n (\%) & n (\%) & n (\%) & n (\%) & n (\%) & n (\%) & n (\%) \\
\hline 38 (39.2) & $28(28.9)$ & 21 (21.6) & $7(7.2)$ & $3(3.1)$ & - & - \\
\hline 73 (75.3) & 18 (18.6) & $6(6.2)$ & - & - & - & - \\
\hline $50(51.5)$ & 19 (19.6) & $19(19.6)$ & $6(6.2)$ & $3(3.1)$ & - & - \\
\hline 84 (86.6) & 7 (7.2) & $4(4.1)$ & $1(1 \%)$ & - & $1(1)$ & - \\
\hline $43(44.3)$ & 34 (35.1) & 17 (17.5) & $3(3.1)$ & - & - & - \\
\hline 61 (62.9) & $10(10.3)$ & $11(11.3)$ & $10(10.3)$ & $2(2.1)$ & $3(3.1)$ & - \\
\hline 93 (95.9) & $2(2.1)$ & $2(2.1)$ & - & - & - & - \\
\hline 34 (35.1) & 18 (18.6) & $23(23.7)$ & $9(9.3)$ & 8 (8.2) & $3(3.1)$ & $2(2.1)$ \\
\hline 33 (34) & $43(44.3)$ & $17(17.5)$ & $3(3.1)$ & $1(1)$ & - & - \\
\hline 70 (72.2) & 17 (17.5) & $9(9.3)$ & $1(1)$ & - & - & - \\
\hline 72 (74.2) & 17 (17.5) & $4(4.1)$ & $4(4.1)$ & - & - & - \\
\hline $12(12.4)$ & $16(16.5)$ & 24 (24.7) & $21(21.6)$ & $\begin{array}{l}19 \\
(19.6)\end{array}$ & $5(5.2)$ & - \\
\hline 19 (19.6) & $42(43.3)$ & $20(20.6)$ & $5(5.2)$ & $6(6.2)$ & $4(4.1)$ & $1(1)$ \\
\hline 28 (28.9) & $29(29.9)$ & $20(20.6)$ & $8(8.2)$ & $6(6.2)$ & $5(5.2)$ & $1(1)$ \\
\hline 21 (21.6) & 30 (30.9) & 28 (28.9) & 8 (8.2) & $8(8.2)$ & $2(2.1)$ & - \\
\hline $16(16.5)$ & 35 (36.1) & 29 (29.9) & $7(7.2)$ & $6(6.2)$ & $3(3.1)$ & $1(1)$ \\
\hline $4(4.1)$ & $3(3.1)$ & 12 (12.4) & 15 (15.5) & $\begin{array}{l}24 \\
(24.7)\end{array}$ & 33 (34) & $6(6.2)$ \\
\hline 30 (30.9) & 37 (38.1) & $21(21.6)$ & $1(1)$ & $3(3.1)$ & $4(4.1)$ & $1(1)$ \\
\hline 13 (13.4) & 35 (36.1) & $24(24.7)$ & $9(9.3)$ & $8(8.2)$ & $6(6.2)$ & $2(2.1)$ \\
\hline
\end{tabular}




\begin{tabular}{|c|c|c|c|c|c|c|c|}
\hline & $\begin{array}{l}\text { Very much } \\
\mathrm{n}(\%)\end{array}$ & $\begin{array}{l}\text { Much } \\
\mathrm{n}(\%)\end{array}$ & $\begin{array}{l}\text { A bit more } \\
\mathrm{n}(\%)\end{array}$ & $\begin{array}{l}\text { Moderately } \\
\mathrm{n}(\%)\end{array}$ & $\begin{array}{l}\text { A little } \\
\mathrm{n}(\%)\end{array}$ & $\begin{array}{l}\text { Very little } \\
\text { n (\%) }\end{array}$ & $\begin{array}{l}\text { None } \\
\mathrm{n}(\%)\end{array}$ \\
\hline $\begin{array}{l}\text { 17. When you consider all these features above, } \\
\text { how much do you trust yourself in maintaining } \\
\text { anticoagulant treatment? }\end{array}$ & $34(35.1)$ & $43(44.3)$ & $12(12.4)$ & $4(4.1)$ & $4(4.1)$ & - & - \\
\hline $\begin{array}{l}\text { 18. How well do you think you understand the } \\
\text { medical causes of your anticoagulant treatment? }\end{array}$ & $7(7.2)$ & $24(24.7)$ & $16(16.5)$ & 18 (18.6) & 19 (19.6) & $12(12.4)$ & $1(1)$ \\
\hline $\begin{array}{l}\text { 19. How much do you feel safe due to your } \\
\text { anticoagulant treatment? }\end{array}$ & $14(14.4)$ & 31 (32) & $26(26.8)$ & $5(5.2)$ & 15 (15.5) & $4(4.1)$ & $2(2.1)$ \\
\hline $\begin{array}{l}\text { 21. When you consider all these features above, } \\
\text { how much does the anticoagulant treatment have a } \\
\text { positive effect on your life? }\end{array}$ & 12 (12.4) & 37 (38.1) & $32(33)$ & $10(10.3)$ & $4(4.1)$ & $2(2.1)$ & - \\
\hline $\begin{array}{l}\text { 23. When you consider all these features above, } \\
\text { how much do you satisfied with the anticoagulant } \\
\text { treatment? }\end{array}$ & 12 (12.4) & $41(42.3)$ & 28 (28.9) & $11(11.3)$ & $2(2.1)$ & $3(3.1)$ & - \\
\hline $\begin{array}{l}\text { 25. To what extent would you recommend this } \\
\text { type of treatment to someone who has to start } \\
\text { an anticoagulant treatment due to the disease or } \\
\text { treatment? }\end{array}$ & $39(40.2)$ & $34(35.1)$ & 17 (17.5) & $5(5.2)$ & $2(2.1)$ & - & - \\
\hline
\end{tabular}

and above, and $61.4 \%$ were women. In many studies, the average age of patients receiving anticoagulant treatment was found to be above 55 years $(19,20,24)$. Our study is similar to the studies performed in terms of sociodemographic features. Similar to the literature, in our study, almost all patients (95.9\%) had a comorbid disease accompanying their current disease $(10,19)$.

In most studies investigating warfarin use, atrial fibrillation was found as the most common warfarin treatment cause (25). Sjögren et al. (26) found that the most common indication was atrial fibrillation with a ratio of $68 \%$, and Rojas-Fernandez et al. (27) reported this ratio as $63 \%$. In our study, the most common indication for warfarin use was atrial fibrillation, which complies with the literature.

Almeida et al. (18) found that the rate of patients using warfarin for 1 year or more was 79.2\%. Connock et al. (7) and Appelboam and Thomas stated that OAC drugs should generally be used for a long time. Our study determined that the majority of patients (79.4\%) had been using warfarin for two years and longer, and this finding is in line with the literature.

In the original study wherein DASS was developed by Samsa et al. (14), the total scale mean score was found as 55.0 \pm 17.6 . This mean score was found as $57.9 \pm 16.5$ in Pelegrino et al.'s (16) study, as $46.4 \pm 8.6$ in Oliveira-Kumakura et al.'s (20) study conducted on patients with stroke, and as 67.1 \pm 18.2 in another study (18). In a study comparing warfarin with other anticoagulants, warfarin satisfaction was found to be slightly lower than other drugs (28).

When the studies conducted in our country are considered, Yıldırım and Bayık-Temel (13) found the total scale mean score as $85.0 \pm 25.1$ where they adapted the scale to Turkish, whereas Mert et al.'s (17) study of elderly patients found the score as $68.9 \pm 22.6$ and Uçar's (21) thesis study found the score of $61.71 \pm 19.34$. The study results of Yıldırım and Bayık-Temel (13) and Mert et al. (17) demonstrate that satisfaction with anticoagulant use is worse in our country.

Our study obtained a total average score of $57.67 \pm 14.56$; hence, we conclude that patients who received home health care were better satisfied and perceived the problems they experienced less. It is believed that factors such as a regular follow-up of patients receiving home health services, lack of additional burdens such as hospital appointments and transportation costs, and sharing responsibilities with caregivers contribute to the satisfaction perception, thereby improving the perception of the patients' home health services.

Previous studies have shown that patients experience more problems and adverse effects as they get older $(12,18)$. Almeida et al. (18) found that the satisfaction and quality of life perception of patients in the age group of 41-65 years were better than the patients aged 65 years and older. Although no significant relationship was found between the age factor and satisfaction level in our study, this situation is believed to be facilitated by the fact that treatment management getting difficult by age is shared with the caregiver and the health care team in patients receiving home care.

Uçar's (21) study found a significant relationship among gender, scale total score and subdimension mean scores; additionally, the study found that men were having lower satisfaction as compared to women. Moreover, Yıldırım and Bayık-Temel's (13) study found that gender does not affect satisfaction with OAC use. Our study, in which the level of satisfaction between men and women is similar, is compatible with Yıldırım and Bayık-Temel's (13) study. 


\section{Table 4. Evaluation of results according to sociodemographic and clinical features of participants}

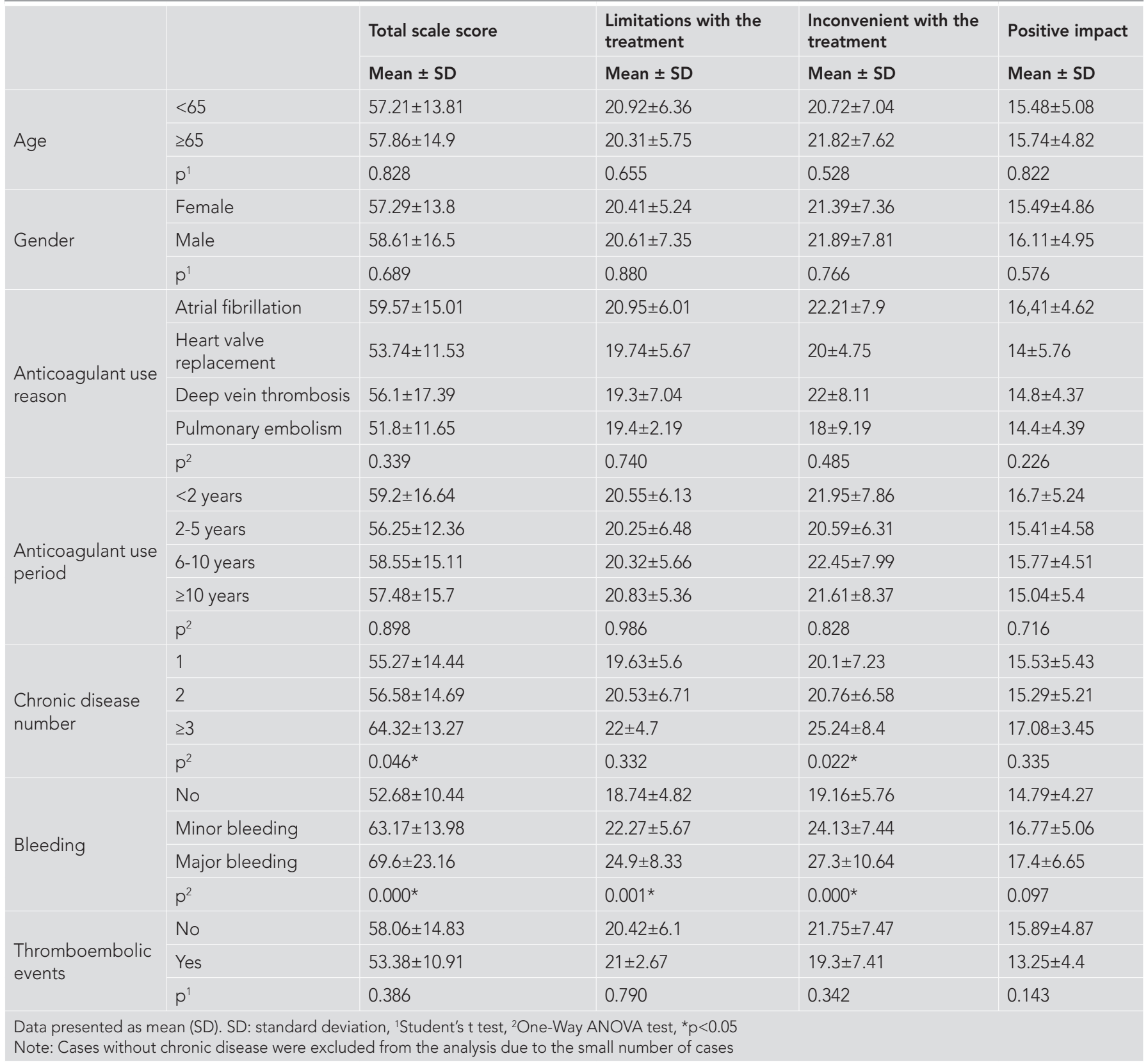

It has been reported that the costs related to disease burden, hospitalisation and access to care services are incurred because of the emergence of complications of each chronic disease $(29,30)$. Yıldırım and Bayık-Temel's (13) study found that burdens and difficulties were experienced more often with an increasing number of chronic diseases. Furthermore, Almeida et al.'s (18) study showed that the presence of additional chronic disease negatively affected the treatment satisfaction, whereas another study found no significant relationship (21). In our study, it is believed that with the increase in the number of chronic diseases, the perception of satisfaction worsens, thereby increasing the burden and difficulties caused by warfarin use. It can be attributed to the burdens caused by chronic diseases and the increasing use of multiple drugs.
Almeida et al. (18) found that patients who received treatment for more than a year had more positive perceptions. Our study found no relationship between treatment time and anticoagulant satisfaction, similar to the study performed by Mert et al. (17).

Previous studies have found that the side effects experienced during warfarin use negatively impacted the satisfaction level of patients $(13,18)$. Furthermore, Sjögren et al.'s $(26)$ study found that the patients had an annual risk of thromboembolic events of $2.65 \%$ and a major bleeding risk of 2.24\%. Yıldırım and Bayık-Temel's (13) study found that the rate of bleeding was $35.2 \%$. Almeida et al. (18) found the bleeding rate to be $37.5 \%$. Yıldırım and BayıkTemel (13) found that individuals with a history of bleeding had more problems in the subdimensions of restrictions, burdens 
and difficulties and had worse satisfaction. Our study observed that the state of having thromboembolic events did not affect the perception of satisfaction. However, those who experienced bleeding during treatment were found to have a higher total scale, and all the subdimension mean scores were higher than those who did not experience bleeding. Our study was found to be in compliance with the literature in this aspect. It is believed that the history of bleeding restricts patients more, increases their responsibilities, such as taking the medication regularly and not interrupting their INR follow-ups, thereby worsening their satisfaction.

\section{Study Limitations}

The limitations of the study were that the study only included patients using warfarin, and the study had a relatively small sample size. Additionally, it is believed that the answers given to the questions about travel, work life and daily work asked to this group of patients who need home care service due to their presence of DASS may be misleading.

\section{CONCLUSION}

As a result, it was found that satisfaction with warfarin use was not poor in patients receiving home care services but a history of bleeding complications while using warfarin and the presence of additional chronic disease worsened treatment satisfaction in our study.

The vast majority of home care patients experience difficulties in the management of medical processes due to advanced age, functional dependencies and chronic diseases. It is believed that consultancy attempts should be planned by health care professionals, and services should be expanded according to the needs of patients, especially those with bleeding problems, multiple morbidities and difficulties in going to control visits. Thus, patients' adherence to treatment and perception of satisfaction can be increased.

Ethics Committee Approval: Ethics committee approval was obtained from the relevant institution on 05.04.2017 (approval no: 36).

Informed Consent: The objective of the study was explained to all the participants, and their informed consent was obtained before their participation in the study.

Peer-review: Externally peer-reviewed.

Author Contributions: Surgical and Medical Practices - S.A., O.B.; Concept - S.A., S.T.K., O.B.; Design - S.A., S.T.K., O.B.; Data Collection or Processing - S.A., S.Ö., O.B.; Analysis or Interpretation - S.A., S.T.K., S.Ö., O.B.; Literature Search - S.A., S.T.K., O.B.; Writing - S.A., S.T.K, S.Ö., O.B.

Conflict of Interest: No conflict of interest was declared by the authors.

Financial Disclosure: The authors declared that this study received no financial support.

\section{REFERENCES}

1. Sağlık Bakanlığınca sunulan evde sağlık hizmetlerinin uygulama usul ve esasları hakkında yönerge. Son Erişim Tarihi: 01.09.2020. Erişim adresi: https://hsgm.saglik.gov.tr/dosya/mevzuat/yonergeler/evde_saglik_ hizmeti_yonerge.pdf

2. Van Walraven C, Hart RG, Connolly S, Austin PC, Mant J, Hobbs FD, et al. Effect of age on stroke prevention therapy in patients with atrial fibrillation: the atrial fibrillation investigators. Stroke 2009; 40: 1410-6.

3. Grunau BE, Wiens MO, Harder KK. Patient self-management of warfarin therapy. Can Fam Physician 2011; 57: e292-8.

4. Kirchhof P, Benussi S, Kotecha D, Ahlsson A, Atar D, Casadei B, et al. ESC Guidelines for the management of atrial fibrillation developed in collaboration with EACTS. Eur Heart J 2016; 37: 2893-962.

5. Powers WJ, Rabinstein AA, Ackerson T, Adeoye OM, Bambakidis NC, Becker K, et al. 2018 Guidelines for the early management of patients with acute ischemic stroke: a guideline for healthcare professionals from the American Heart Association/American Stroke Association. Stroke 2018; 49: 46-99.

6. Ommaty R. Vademecum-Kardiyoloji. İstanbul: Medical Tribune Yayıncılık; 2009; 302-420

7. Connock M, Stevens C, Fry-Smith A, Jowett S, Fitzmaurice D, Moore D, et al. Clinical effectiveness and cost-effectiveness of different models of managing long-term oral anticoagulation therapy: a systematic review and economic modelling. Health Technol Assess 2007; 11: iii-iv, ix-66. doi: 10.3310/hta11380.

8. Elewa HF, DeRemer CE, Keller K, Gujral J, Joshua TV. Patients satisfaction with warfarin and willingness to switch to dabigatran: a patient survey. J Thromb Thrombolysis 2014; 38: 115-20.

9. Wang $\mathrm{Y}$, Kong MC, Lee LH, Ng HJ, Ko Y. Knowledge, satisfaction, and concerns regarding warfarin therapy and their association with warfarin adherence and anticoagulation control. Thromb Res 2014; 133: 550-4.

10. Köksal AT, Avşar G. What patients taking oral anticoagulants know and do about anticoagulant therapy: evaluation of patients in a cardiology service. Balikesir Saglik Bil Derg 2015; 4: 137-42.

11. Briggs AL, Jackson TR, Bruce $S$, Shapiro NL. The development and performance validation of a tool to assess patient anticoagulation knowledge. Res Social Adm Pharm 2005; 1: 40-59.

12. Bajorek BV, Krass I, Ogle SJ, Duguid MJ, Shenfield GM. Warfarin use in the elderly: the nurses' perspective. Aust J Adv Nurs 2006; 23: 19-25.

13. Yıldırım JG, Bayık-Temel A. The validity and reliability of Turkish version of the Duke anticoagulation satisfaction scale. Turk Gogus Kalp Damar 2014; 22: 761-72.

14. Samsa G, Matchar DB, Dolor RJ, Wiklund I, Hedner E, Wygant G, et al. A new instrument for measuring anticoagulation related quality of life: development and preliminary validation. Health Qual Life Outcomes 2004; 2: 22.

15. Prins MH, Guillemin I, Gilet H, Gabriel S, Essers B, Raskob G, et al. Scoring and psychometric validation of the Perception of Anticoagulant Treatment Questionnaire (PACT-Q). Health Qual Life Outcomes 2009; 7: 30.

16. Pelegrino FM, Dantas RA, Corbi IS, da Silva Carvalho AR, Schmidt A, Pazin Filho A. Cross-cultural adaptation and psychometric properties of the Brazilian-Portuguese version of the Duke Anticoagulation Satisfaction Scale. J Clin Nurs 2012; 21: 2509-17.

17. Mert H, Küçükgüçlü Ö, Sezgin D, Demir Barutçu C, Yardımcı T, Erünal $M$. Examine the satisfaction status of elferly patients related to the oral anticoagulant use. Türkiye Klinikleri J Intern Med Nurs-Special Topics 2016; 2: 43-50.

18. Almeida GdeQ, Noblat Lde A, Passos LC, do Nascimento HF. Quality of life analysis of patients in chronic use of oral anticoagulant: an observational study. Health Qual Life Outcomes 2011; 9: 91.

19. Carvalho AR, Ciol MA, Tiu F, Rossi LA, Dantas RA. Oral anticoagulation: the impact of the therapy in health-related quality of life at six-month follow-up. Rev Lat Am Enfermagem 2013; Spec No: 105-12.

20. Oliveira-Kumakura ARS, Pacheco I, Oliveira HC, Rodrigues RCM. Relationship between anticoagulant medication adherence and satisfaction in patients with stroke. J Neurosci Nurs 2019; 51 :229-34.

21. Uçar A. Varfarin tedavisi alan hastaların tedaviye yönelik memnuniyet algıları. Yüksek Lisans Tezi. Konya: Selçuk Üniversitesi Sağlık Bilimleri Enstitüsü, Hemşirelik Anabilim Dalı; 2017.

22. Yılmaz M, Sametoğlu F, Akmeşe G, Tak A, Yağbasan B, Gökçay S, et al. In-home health services as an alternative form of presentation of patient care. Istanbul Med J 2010; 11: 125-32. 
23. Karaman D, Kara D, Yalçın Atar N. Care needs and disease states of Individuals, who home health care services are provided evaluating: example of Zonguldak province. Gümüşhane Üniversitesi Sağlık Bilimleri Dergisi 2015; 4: 347-59.

24. Alışır MF, Keçebaş $M$, Beşli F, Çalışkan $S$, Güngören F, Yıldırım $A$, et al. The rates of effective inr levels and the relationship with etiology in patients with warfarin treatment. Turkiye Klinikleri J Med Sci 2013; 33: 868-73.

25. Papaioannou A, Kennedy CC, Campbell G, Stroud JB, Wang L, Dolovich $L$, et al. A team-based approach to warfarin management in long term care: a feasibility study of the MEDeINR electronic decision support system. BMC Geriatr 2010; 10: 38.

26. Sjögren V, Grzymala-Lubanski B, Renlund H, Friberg L, Lip GY, Svensson PJ, et al. Safety and efficacy of well managed warfarin. A report from the Swedish quality register Auricula. Thromb Haemost 2015; 113 :1370-7.
27. Rojas-Fernandez CH, Goh J, Hartwick J, Auber R, Zarrin A, Warkentin M, et al. Assessment of oral anticoagulant use in residents of long-term care homes: evidence for contemporary suboptimal use. Ann Pharmacother 2017; 51: 1053-62.

28. Stephenson JJ, Shinde MU, Kwong WJ, Fu AC, Tan H, Weintraub WS. Comparison of claims vs patient-reported adherence measures and associated outcomes among patients with nonvalvular atrial fibrillation using oral anticoagulant therapy Patient Prefer Adherence 2018; 12: 10517.

29. Dedeli Ö. Karadakovan A. Investigation of complementary and alternative medicine practice and drug use in the elderly. Spatula DD 2011; 1: 23-32.

30. Ünsal A, Demir G. The prevalence of chronic disease and drug use in the elderly in central Kırşehir. Turk J Geriatr 2010; 13: 244-51. 